\title{
W 7-1
}

H I V-1 外被糖蛋白 g p 120 により誘導されるアポトーシスに対する

免疫抑制削 F K 506 の抑制効果

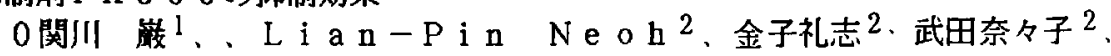

菱川隆史 ${ }^{2}$ 、橋本博史 ${ }^{2}$ 、飯田昇 ${ }^{1}$ 、広瀬倰一 ${ }^{-1}$ (1、順天堂伊豆長岡病院、

内科。2、順天堂大膠原病内科)

目的）H I V感染でのC D 4 陽性細胞隇少の機序としてアポトーシスの関与が指摘される。 H IV外被蛋白 g p 120 によるアボトーシス誘導の可能性を検索し、こうした実験系で のアボトーシス抑制における免疫抑制郕F K 506 の効果を検討した。

方法) 正常ヒト末梢リンバ球 (PB M C) にリコンビナントg p 120 と杭T細胞レセブ 夕ー (TCR) 抗体刺激を加えアポトーシスの誘導を試みた。精製した正常ヒト末梢C D 4 陽性リンバ球ではアポトーシス誘導のために、更に杭 g p 120 抗体による刺激を加え た。アポトーシスは、D N A ラターフォーメイション及び、トリパンフルー法にて調べた。 種々の瀑度のFＫ５０６をこれらの実験系に添加しアポトーシスの抑制効果を調べた。T NFーaはE L I S Aにて測定した。

結果) 1 I P B M Cに g p 120 及び杭 T C R 抗体の刺激を加えることによって、また精 製C D 4 陽性T細胞には、更に杭 $\mathrm{g}$ p 1220 抗体刺漖を加えることによってアポトーシス を誘導しえた。2、FK 506 は、こうした系でのアポトーシスに対しその量依存的に抑 制効果を示した。3，g p 120 は、マクロファージを刺激LT N F- - 2 の産生を促すが、 FＫ５０6はこの産生を抑制し、このことがアポトーシス抑制の一因であることが示唆さ れた。

結語）ｇｐ１２０は、T細胞アボトーシスを誘導しＦＫ５０６は、こうした細胞死を抑制 した。

W 7-2

CD 4*細胞による甲状腺濾胞細胞障害性の検討

○川上純、江口勝美、松岡直樹、坪井雅彦、河部庸次郎、

石川直文 ${ }^{*}$ 、伊藤國彦* 、長瀧重信

(長崎大学第一内科、“伊藤病院)

【目的】私達は甲状腺滤胞細胞にはF a s 依存性アポトーシスが惹起され、TSHはこれ を抑制することを報告した。今回、活性化 C D 4 細胞による滤胞細胞障害性およびTSHの それに対する抑制効果を検討したので報告する。【方法】滤盷細胞は、手術時に得られ た組織より、C D 4 細胞は健常人末梢血からマグネティックビーズ法にて分傩した。F as およびFasリガンドの発現は、抗体によるフローサイトメトリー法により検出した。滤胞 細胞によるCD4*細胞の活性化およびその活性化C D 4 細胞による甲状腺滤胞細胞障害は、 ${ }^{5}{ }^{1} \mathrm{Cr}$ で標識した滤胞細胞とCD4*細胞をSEB存在下で混合培盖し、 ${ }^{5}{ }^{1} \mathrm{Cr}$ の遊離にて算定し た。【結果】(1)滤胞細胞は無刺激でもF asを発現し、IFN-y刺激によりその発現は著明に 增大した。(2)無刺激 $\mathrm{CD} 4$ *細胞はF as リガンドの発現が軽度で、滤胞細胞を障害しなかっ たか、IF - $\gamma$ 刺激滤胞細胞とSEB存在下で混合培養するとFas リガンドの発現は著明に 增大し、滤胞細胞を障害した。この障害はhFas - F c 添加にて抑制された。(3)TSH 添加は

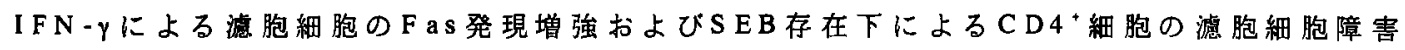
能を抑制した。【結語】活性化 C D 4*細胞はF as - F as リガンドシステムで甲状腺滤胞細胞 を障害した。TS Hは滤胞細胞のFas 依存性アポトーシスを抑制し、甲状腺の腫大に関与 することが示唆された。 
w 7-3

特発性心筋症におけるアポトーシスの解析

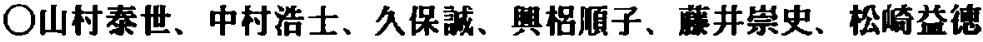
(山口大学 第二内科) 小林信之 (山口大学 寄生体学鿁座)

[目的］近年、免疫学や腫癌学などをはじめとして、細胞障害や細胞死におうけるアポト一 シスの概念が提唱されている。そこで、慢性的な心筋障害が存在すると考えられる特発性心 筋症 (DCM、HCM) におけるアポトーシスの関与の有無を、心内膜下心筋生検組織標本を用 いて検討した。[方法］当科にて臨床及び心筋生検所見より診断した（i ）DCM群10例（ii） HCM群10例 (iii ) コントロール群 3 例の連続組織標本を用いた。Fas抗原の発現は抗ヒトFas抗 体を用いた酳素抗体免疫染色法（LSABキット、DAKO社）にてその発現の強さを半定量的に 検討した。また、イムノベルオキシダーゼ直接検出法 (Apo-tag、Oncor社) を用いてapotic cell を検出し、無作為 5 視野の強拡大写真より標本全心筋細胞中の apotic cell $の$ 出現率を算出 した。更に、Fas抗原の発現の程度ならびにapotic cell の出現率とLVEDd, LVEF,Pcwとの関係 を検討した。[結果] Fas抗原はDCM群ではHCM群に比較して強く発現していた。アポトーシ スの検討では DCM群10例中6例、HCM群5例中1例がapotic cell陽性であり、その出現率はDCM 群 $8 \%$ 、HCM群 1\%であった。また apotic cell はFas抗原発現細胞とよく一致していた（一致 率64\%) 。LVEFが40\%未満の症例でapotic cell の出現率が有意に高く、また、Fas抗原の発現 が強いほどLVEDdが大きくなる傾向がみられた。[総括] 心筋疾患の病巣進展にFasシステム を介したアポトーシスの関与が示唆され、また、DCMではHCMに比較して、その関与が大き いと考えられた。

W 7-4

免疫性血小板減少症におけるアポトーシス関連マーカーの測定 野村昌作、香川英生、福原資郎

関西医科大学第一内科

【目的】自己免疫疾患では、自己反応性リンパ球クローンの増殖がみられ、 その原因のひとつとして、アポトーシスの異常が注目されている。今回我々は、 免疫性血小板減少症 (ITP) を対象としてアポトーシス関連マーカーについて測 定したので報告する。【対象・方法】対象は当院で経過観察中の慢性 ITP22例 で、年齢は19-72歳 (中央值 44)、性別は男性 3例、女性 19例である。まず、患者 末梢血から分離したリンパ球を用いて、フローサイトメトリーによる細胞表面 Fas抗原の測定を行い、続いて、low FSC / high RSC のスキャッター分画に含ま れる細胞のAnnexin Vおよびbcl-2 蛋白の陽性率を測定した。さらに患者血墏を 用いて、ELISA法による可溶性Fas抗原 (sAPO-1/Fas)の測定を行った。なお、対照 として20例のSLE患者を使用した。【結果】リンパ球表面のFas抗原陽性率は平 均 3.12\%であり、SLE(2.19\%) よりも高值であった。一方、Iow FSC / high RSC 分画 では、Annexin Vとbcl-2蛋白の陽性率には有意な正相関が認められ、これはSLEで も同樣であった。さらに SAPO-1/Fasは、平均 $6.6 \%$ と、SLE(43.9\%)よりもかなり低值 であった。【結語】ITP発症のメカニスムにおけるアポトーシスの関与は、 SLEとは異なるものであると考えられた。 


\section{W 7-5}

シェーグレン症候群における組織障害機構の検討

Fas-Fas ligandと細胞障害顆粒を中心に

○斉藤佳子、鈴木円*、藤原勉**、坪田一男**、関根浩美、竹内勤、安倍達

(埼玉医大総合医療センター2内、*口腔外科、**東京歯科大学市川病院眼科)

〔目的〕近年リンパ球による細胞障害の機序にはFas-Fas ligandを介する系と細胞障害 顆粒を介する系があることが明かにされている。シェーグレン症候群（SjS）の腺破壊 の機序を解明する目的でFas-Fas ligand、細胞障害顆粒の発現につき末梢血リンパ球、睡 液腺涙腺組織にて検討した。〔方法〕1.Fas-Fas ligandの発現；SjS と正常人コントロール の末梢血リンパ球あるいは唾液腺、沪腺組織の凍結標本を用い、間接蛍光抗体法でフロ ーサイトメトリー、ACASにて解析した。2.細胞障害顆粒の発現；SjSと正常人コントロ ールの末梢血リンパ球を可溶化し、Perforin、TIA-1の発現をCD4、8、16、56との二重染色 にてFACScanにて解析した。唾液腺、涙腺組織の標本はPerforin、TIA-1の発現につきCD4、 CD8 と二重染色を施行し、ACASにて解析した。〔結果〕1.SjSの一部の症例で唾液腺、 涋腺組織においてFas-Fas ligandが極めて強く発現されていた。2.SjSの末梢血リンパ球の 細胞質内、睡液腺、涙腺組織にPerforin、TIA-1が発現されており二重染色によりTIA-1は $\mathrm{CD} 4$ 陽性T細胞中に存在することが明かとなった。〔結語〕SjSの腺破壊には個々の症 例でFas-Fas ligand と細胞障害顆粒のそれぞれが異なる調節機構を介して関与しているこ とが明かとなった。

\section{W 7-6}

SLE 患者の可溶性 F asについての検討

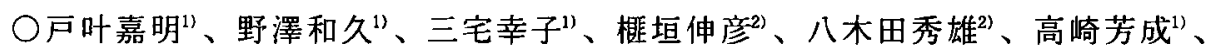
奥村 康 $^{2)}$ 、橋本博史 ${ }^{1)}\left({ }^{1)}\right.$ 順天堂大学 膠原病内科、党同 免疫)

【目的】SLE患者の血中の可溶性 F as を測定し、活性化リンパ球のマーカー及びリンパ球 減少との関連について検討した。

【対象】ACRの診断基準を満たし、SLEDAIで 8 point 以上の活動期 SLE患者 35 例を対 象とした。可溶性Fas、CD4、CD8、CD23 はそれぞれに対するモノクロナール抗体を用い たSandwitch ELISA 法で测定した。

【結果】SLE 患者の血中可溶性F a s は正常人に比し、有意に增加していた。可溶性 F a s 量は可溶性 CD4 の量と有意に相関し、可溶性 F as の出現か CD4 陽性 $\mathrm{T}$ 細胞の活性化と関連 していることが示唆された。可溶性 Fas と臨床所見との関連を検討してみると、リンパ球 減少の認められる症例で、可溶性 Fasが低值を示す傾向が認められた。

【結論】SLEの可溶性 Fasの異常に関しては報告により差はあるが、我々の検討した活動期 SLEでは正常人に比し、有意に増加していた。可溶性F as は可溶性 CD4 の量と相関し、リ ンパ球減少の認める症例では低下傾向を認めることから、SLEにおいては、CD4 陽性 T 細 胞の活性化とともに、可溶性 Fas が出現し、CD4 陽性 T 細胞のFas - F a s リガンドを介し たActivation induced cell deathを阻害することにより CD4 陽性 T 細胞の活性化を 促進している可能性が示唆された。 
W 8-1

細胞内寄生菌に対する免疫抵抗性とNO

○小出幸夫、吉田篤司、内嶋雅人（浜松医大・微生物）

[目的] 細胞内寄生菌のモデルとしてBCGを用いた。これに対するマウスの免疫抵抗性には 系統差があることが知られている。そこで、そのメカニズムを検討した。［方法］C57BL/10

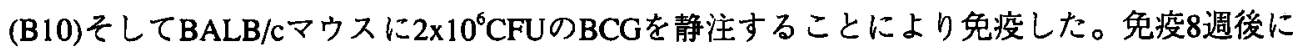
$2 \times 10^{7}$ CFUのBCGをマウスに経静脈的に感染させた。逆転写酵素(RT)-PCRによるサイトカイン 及びNO生成酵素（iNOS）mRNAの定量は常法のごとく行なった。[結果］B10マウスに比し、 BALB/cマウスはBCGに対する免疫抵抗性が弱いことが判明した。この免疫抵抗性はIFN- $\gamma$ KOマウスで認められないこと及びNOS阻害剤で低下することより、IFN- $\gamma$ によNOの発現 が重要な役割を果たすことが示唆された。BALB/cにおけるIFN- $\gamma /$ NOの発現不全の原因を 検討し、以下の結論を得た。[結語］BALB/cのBCG感受性の原因はマクロファージにあり、 BCG刺激によるIL-12mRNAの発現能及びIFN- $\gamma$ 反応してiNOSmRNAを発現させる能力が弱い ことが判明した。T細胞のIL-12に対する反応性は低下していなかった。この理由により、 BALB/cマウスはB10マウスに比しBCG感染に対する免疫抵抗性が弱いと考えられる。

\section{W 8-2}

敗血症性ショックとNO

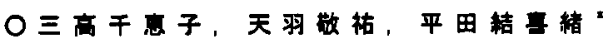

(束京医科齿科大学医学部萧中治部，第 2 内科”)

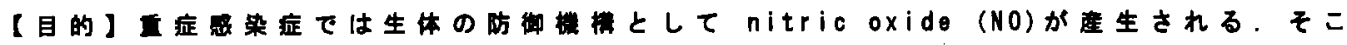
で政血症性ショックにおける

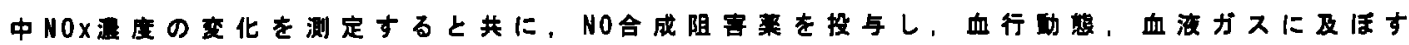

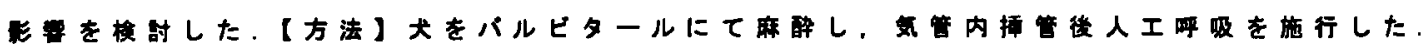

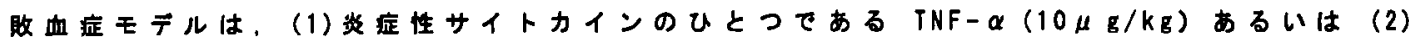
エンドトキシン $(250 \mathrm{ng} / \mathrm{kg} / \mathrm{h} ， 2 \mathrm{~h})$ 投与によって作成L，血中NOx浱度，血行的能を测定

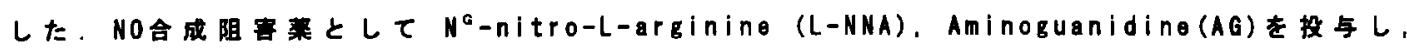

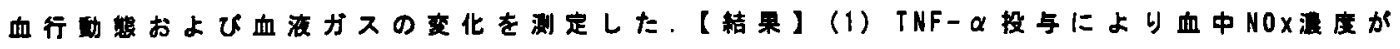

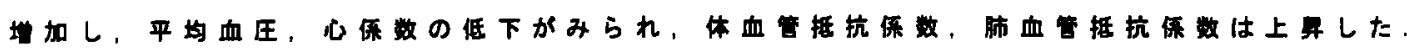

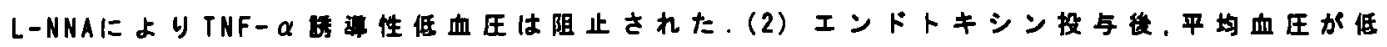

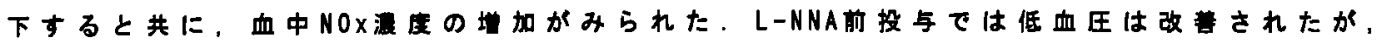

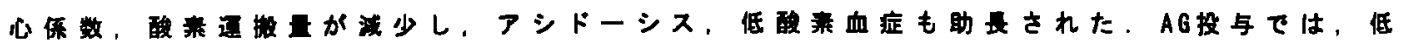

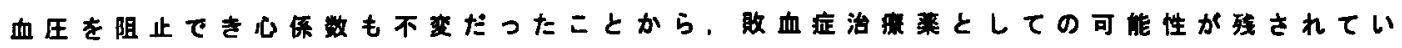

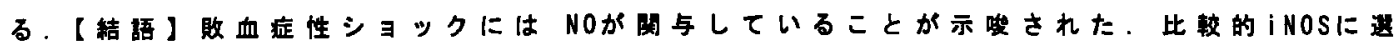

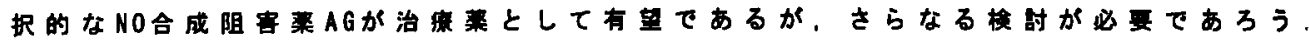




\title{
W 8-3
}

免疫抑制薬及び抗アレルギー薬のNO産生に及はすす効果

中木敏夫（慶應義塾大学薬理学）

[目的] シクロスポリンA は副作用として高血圧を引き起こす。我々は、シクロスポリンAの 血管平滑筋NO生成酵素(NOS)の誘導抑制作用を想定した。一方、トラニラストは線維芽細胞增殖 抑制作用や心肥大抑制作用をもつ。NOが細胞増殖抑制効果を持つことから、トラニラストがNO 誘導を促進する可能性を考えた。

[万法] ラットの大動脈平滑筋細胞を培養し、サイトカイン及びLPS、シクロスポリンA ある いはトラニラストを組み合わせて培地に加えた。NO産生は細胞上清中の $\mathrm{NO}_{2}{ }^{-}$をGriess法により測 定した。NOSのウエスタン解析及びノーザン解析を行った。

[結果] シクロスポリンA はサイトカインやLPSにより、 $\mathrm{NO}_{2}$ 産生誘導、NOS 蛋白及び NOS mRNAの誘導を抑制した。カルシニューリンの別の阻害薬である FK 506 はカルシニューリンを 阻害するに十分な濃度 $(1 \mathrm{mM})$ を添加しても、 $\mathrm{NO}_{2}^{-}$産生誘導に影響を与えなかった。一方、ト ラニラストはPDGFによる細胞数、DNA合成の増加を濃度依存性に抑制し、またサイトカイン・ LPSによるNOS誘導を濃度依存性に増強した。

[結語] シクロスポリンA はカルシニューリンの阻害以外の機序によってNOS 誘導を抑制した 可能性が考えられた。トラニラストはNO誘導増強を介する作用及び直接作用によりPDGFによる 細胞增殖作用を抑制するものと考えられた。

\section{W 8-4}

\author{
NOと活性酸素のクロストークとレドックス制御 \\ 井上正康（大阪市立大学医学部生化学講座）
}

生命維持に不叮久な酸絭の数\%は平時でも高反応性の活性酸素 $\left(\mathrm{O}_{2} ;, \mathrm{H}_{2} \mathrm{O}_{2}, \mathrm{HClO}\right.$, ・OHなど)となり、様々な生体分子と反応して生体防御反応や細胞機能制御に関与する と同時に、病㦔時には組織細胞を障害する。含酸素ラジカルであるNOも生体チオール やへム蛋白と相互作用しながら種々生理作用を発現するが、その体内挙動と分子機構は 尚不明である。演者らは、病紧指们性superoxide dismutase (SOD)や血管内皮指向性 SODを開発し、体内では $\mathrm{O}_{2}$ とNOが常時産生されること、両者のクロストークにより組 織循環動態が部位特異的に制御されること、その乱れが各種疾患の病態增悪因子となる こと、および活性酸素が正常血圧の維持や高血圧病態発症の鍵を握ることを明らかにし てきた。また、短寿命と信じられているNOの寿命が組織細胞内の生理的低酸素分圧下 では極めて長寿命（十数分）、虚血部位では数十分以上にも延長し、その生物作用が強 く発現すること、さらに、NOがミトコンドリア呼吸とATP合成を可逆的に阻害すると 同時に、腹水澏細胞のアポトーシスを誘起することを発見した。本会では、脳および末 梢組織細胞がNOP活性酸菜を分了言語とする情報ネットワークを形成し、組織の血液 循環制御とエネルギー代謝制御を介して細胞の生と死を決定している様相を述べる。 


\section{W 8-5}

媨損場に伴い発生する一酸化窒素（N0）と神経細胞死 ○武内章英 1）2）3）、磯部健一2）、中島 泉 1 ）、木内一志 3 ）

(1)名古屋大学医学部兔疫学、2)国立長寿医療研究センター 老化機構、3)理化学研究所運動遭伝子)

〔目的〕媨グリア細胞は、in vitroにて菌体成分である L P S アサイトカインの剌激 により一酸化空素（N0）を放出することが知られている。今回我々は、線条体損㑥モテ ルにおいて誘道型一酸化空素合成醭素（iNOS）が誘莩される事を見い出した。また、損 偒操作後 $c$-fos なとの im m ediate early geneをはしめ、各種サイトカイン遺伝子の 誘遷も見い出したので、媨損倡後のgliosisについてN0を中心に報告する。

〔方法〕生後 8 週目のラットに对し定位媨手術を行い、線条体片側を一部破境するモテル を㴻立した。破壊された線条体を取り出し、RT-PCR 法により iN O S および各種サイト カインの mRNA 発現量の経時的変化を测定した。in situhybridization及び im m unohistochem istry を行い、iNOSを発現する部位、紐胞を同定した。またNOS の阻害菜であるL-NAME 用いてN0の作用を組織学的に検討した。

〔結果〕壊死を起こした部位と健常腷組織との境界部分に一致して、グリア細胞に iN OS の発現がみられた。この境界領域の神経細胞は、時間とともに徐々に脱落してい くが、L -NAMEの腹胵内投与により神経細胞の脱落が減少した。

〔結語〕gliosis の過程で、機能的に何らかの異常の生じた神経細胞が N されるのではないかと考えられた。 


\section{W 9-1}

慢性関節リウマチ（R A）とＴＣＲＢＪ遺伝子レパトワ

O上阪 等、南木敏宏、宮坂信之（東京医科歯科大学難治疾患研究所

ウイルス・免疫疾患研究部門、第一内科）

〔目的〕ヒト末梢血Tリンパ球のT C R B J 遺伝子レパトワは強く遺伝支配されている。そこで、 R A 一卵性双生児の末梢 C D 4 ・ C D 8 T リンパ球、大家族棈成員のレパトワを解析し、R A の各 サブセットに及はす影響、T C R B と H L A 遺伝子の影響を検討する。

[方法]一卵性双生児末梢Tリンパ球から分離したC D 4 C C D 8 リンバ球扔よび大家族の末梢り ンパ球からR N A を単離し、T C R B J 遺伝子レパトワをP C R - E L I S A 法で比較検討した。 遺伝型は、T C R B 遺伝子型はマイクロサテライトを用いたP C R 法により、H L A 遺伝子は P C $\mathrm{R}$ と特異プローブによるハイブリダイゼーションで決定した。

[結果〕各 BV 遺伝子トランスクリプトに認められた特徵的B J 遺伝子使用はCD 8 T 細胞に比し てC D 4 T 細胞に顕著に認められた。C D 8 T 細胞にはクローナルな増殖が散見されたが、RAの 症例に特異的なものはなかった。大家族を用いた遺伝支配の検討では、これまでのところ H L A に よる影響が強く認められる。

〔結語〕CD 8 T細胞に比してCD 4 T細胞レパトワはより強い遺伝支配を受けている。慢性自己 免疫疾患であるRAは、末梢C D 4 - C D 8 T 細胞にB J 遺伝子特異的変化を及はさず、このこと はレパトワがむしろRAの原因としての役割を演じている可能性を示唆する。

W 9-2

慢性関節リウマチ病变局所に集掅する丁細胞の解析

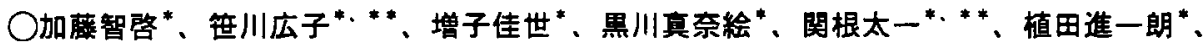

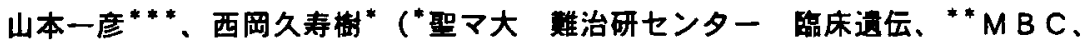
***九大生医研)

[目的]慢性関節リウマチ（RA）の主病变である関節には滑璟堌殖とT細胞浸潤が思められる. この丁細胞の病因論的役割を検封する目的で我々は十細胞受容体（TCR） $\beta$ 鎖の解析によりこれら 丁細胞のクローナリティーを解析した.

[方法] RA患者の末梢血リンパ球，滑液，及ひ滑膜からRNAを調整し，RT-PCR法によりTCR $\beta$ 鎖 息伝子を増幅し、1）１3 の機能的」 $\beta$ 遗伝子の使用頻度決定、2）SSCP法によるT細胞のクロー ナリティーの解析、3）塩基配列の決定を行った。

[結果］1）末梢血リンパ球に較ベ、滑液リンパ球では 1 ないし 2 個のJ $\beta$ 領域が優位に使われてい た.これは特定のT細胞のクローンの集積によると判明した. 約 1 年を経ても同一の丁細胞クローン が集積していることが分かった。2) SSCP法による解析でも、RA患者の滑液滑膜からT細胞のク ローナルな集稍を示すバンドが検出された．また、同一滑膜内の異なる 2 箇所から同一の丁細胞のク ローンの集積が検出された. さらに，同一患者の䔬なる関節からも同一の丁細胞のクローンの集襀が 検出された.

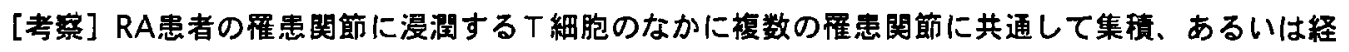
時的にも安定して集㺓する丁細胞りローンの存在が示された．関節組織に共通した抗原を现識して免 癋店をおこしている可能性が考えられた。 


\section{W 9-3}

シェーグレン症候群の涙腺と口唇唾液腺におりる共通のT細胞

○松本功 ${ }^{1,3}$ 、坪田一男 ${ }^{2}$ 、村田秀行 ${ }^{1,3}$ 、北靖应 ${ }^{1}$ 、西岡久寿樹 ${ }^{3}$ 、斉藤康 ${ }^{1}$ 、

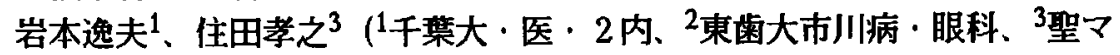
医大・難治研・臨床遺伝)

【目的〕シェーグレン症候群 (SS) では、滬腺 (LG) や口唇唾液腺 (LSG) にCD4陽 性T細胞が著明に浸潤し、それらが病因として重要な役割を果たしていることが知られて いる。我々は両組織に浸潤したT細胞のT細胞レセフター（TCR）を解析することにより、 同症にお引ける自己免疫の発症譏構について解明を試みた。

【方法】4例のSS患者より採取した著明な単核球浸潤を伴うLG，LSG、末梢血リンパ球 (PBL) を対象とした。各榩器に浸潤したT細胞のクロノタイブはRT-PCR後のSSCP法に て検討し、一部のTCRについてはCDR3領域の核酸塩基配列を解析した。

【結果】SSCP解析では、LG，LSGに各V $\beta$ 遺伝子にそれそれ3.6 9.9個、4.8 9.3個のT細 胞クローンの集積が認められた。さらに、各症例において少なくとも6 16個の共通のクロ ノタイブを示すバンドが検出され、それらは両組織において同一のTCRを呈していた。共 通のTCRクローン間では、保持されたアミノ酸がCDR3領域に認められた。

【結語】SS患者のLGに浸潤したT細胞はLSGと同様に抗原刺激により増加していることが 判明した。また、LG,LSGに同一T細胞クローンが認められたことより、両組織に浸潤し た自己反応性T細胞が同一自己抗原により誘導されていること、さらにそのT細胞エビト 一ブは限定されている可能性が示唆された。

\section{W 9-4}

SLEにおけるT細胞クロノタイフ集積と疾患活動性との関係

○植田進一朗 ${ }^{1.2}$, 加藤智辟 ${ }^{1}$, 增子佳世 ${ }^{1}$, 三森明夫 ${ }^{3}$, 狩野庄吾 ${ }^{3}$, 伊藤幸治 ${ }^{2}$, 山本一彦 ${ }^{4}$, 西阙久寿樹 ${ }^{1}$

聖マリアンナ医大難治研 ${ }^{1}$ 東京大学物療内科 ${ }^{2}$ 自治医大アレルギー睡原病科 ${ }^{3}$

九州大学生体防御医学研

[目的]我々はS L E 患者の末梢血 T 細胞クローナリティ一と疾患活動性の関係を $\mathrm{R} \mathrm{T}$ ／ P C R - S S C P 法を用いて解析し, 疾患活動性が上がると末梢血リンバ球数の減少にも かかわらず特定の T 細胞クローンの集皘が增強することを昨年の本学会で報告した：今回 我々は患者末梢血中のＣ４４陽性，ＣＤ８陽性の各Ｔ細胞サブセットについてクローナリ ティーを解析し，疾患活動性との関倸について榙討した。

[万法]S L E 患者末梢血からリンバ球を分踓し，さらに抗 C D 4 抗体，また抗 C D 8 抗 体の結合したマタネットビースを用いてＣＤ４陽性Ｔ細胞とＣＤ８陽性Ｔ細胞とをボジティ ヴセレクションにより回収した。各々のサフセットよりR N A を抽出後, R T - P C R 法 によりT細胞レセフター てそれそれ集皘する $\mathrm{T}$ 細胞クロノタイブを检討した。

[結果] 活動性の高い患者では C D 4 陽性 T 細胞, C D 8 陽性 T 細胞ともにクローナルな 集積が認められた。活動性の低い患者ではC D 8 陽性 T 細胞にクローナルな集皘を認めた が, C D 4 陽性 T 細胞のクローナルな集精は明らかに減少していたＳＬＥの疾患活動性 の高い時に集棈するこれらC D 4 晹性 T 細胞クローンはS L E の病因及び病態に関与して いる可能性があり，現在症例数を增やし，寛解期，再然時についてもさらに検討している. 


\section{W 9-5}

DNAトボイソメラーゼ I / S c l-70(トボ I )と反店する自己反応性 T 細胞の T C R の解析

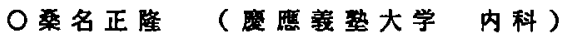

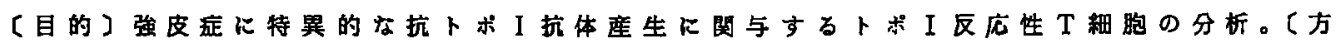

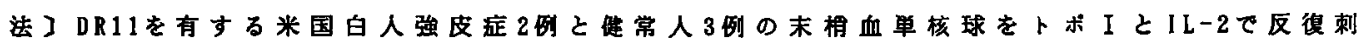

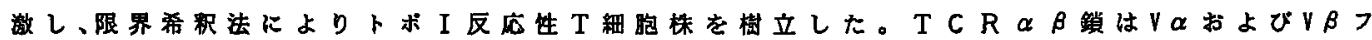
テミリー特異的ブライマーを用いたRT-PCR法で分析した。〔結果〕(1)卜ホIに特異的に反 店する15株（強皮症から7, 健常人から8）のT細胞クローンが得られた。（2）全てのクローン はCD3+CD4+CD8-のヘルパーT細胞で、HLA-DRで拘束され、トボ

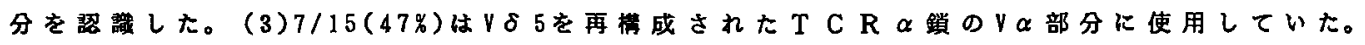
(4) $14 / 15(93 \%)$ はB $20.1 \mathrm{a} / \mathrm{J} \beta 1.1 / \mathrm{C} \beta 1$ を使用していた。（5）CDR3領域のアミ/酸配列は均

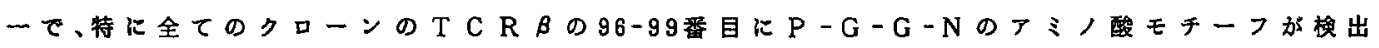
された。（6）同一の T C R $\alpha$ または $\beta$ 鎖を持つクローンが異なる個人から得られた。（7）以 上の特性は強皮症と健常人から得られたクローンで差がなった。〔結㶾つ卜ポ反応性 $\mathrm{T}$ 細胞は正常の T 細胞レバトワの一部で、特定の T C R を発現する自己反応性 $\mathrm{T}$ 細胞が除去さ れるい可能性が示された。強皮应における自己抗体産生は $\mathrm{T}$ 細盷の本質的異常に基すく あのてなく、トレランスを免れたこれらの自己反応性 $\mathrm{T}$ 細胞の活性化によると考えられた。

\section{W 9-6}

自己免疫疾患におけるV $\alpha 24 \mathrm{~J} \alpha \mathrm{Q}$ 陽性 double negative $\alpha \beta \mathrm{T}$ 細胞の役割

○大石嘉則、坂本明美、高橋英則 ${ }^{*}$ 、吉田象二* 、住田孝之**、岩本逸夫、

齋藤 康 (千葉大第二内科、旭中央病院 ${ }^{*} 、$ 聖マリアンナ医大・難治研セ ${ }^{* *}$ )

【目的】活動期SLE患者および浮腫期強皮症患者末梢血中にdouble negative(DN) $\alpha \beta$ T細胞が増 加しており、これらが病態に関与している可能性が示唆されている。一方、自己免疫疾患モテル マウスにおいて、DN V $\alpha 14 \mathrm{~J} \alpha 281$ 陽性T細胞の疾患発症への関与を示す研究が進められている。 今回我々は、ヒトにおいてこの細胞と高い相同性を有するDN V $\alpha 24 \mathrm{~J} \alpha \mathrm{Q}$ 陽性 T細胞の病因的意義 を調べる目的で、活動期SLE患者および浮腫期強皮症患者末梢血中T細胞レセプター(TCR)レパト アの解析を行った。

【方法】SLE患者5例、強皮症患者3例、および健常人コントロール5例の末梢血をFACStarにて CD4/CD8陽性 T 細胞と、DN $\alpha \beta$ T細胞とに分画した。それぞれについて、1）RT-PCR法による TCRV $\beta 、 V \alpha$ 遺伝子発現、2）V $\alpha 24$ 遺伝子のCDR3領域核酸塩基配列について検討した。

【結果】1) SLE、強皮症患者ともに、DN $\alpha \beta$ T 細胞は、TCRV $\beta 、 V \alpha$ 遺伝子発現とも限定され、 $V \alpha 24$ 遗伝子が、全例で認められた。2）患者由来V $\alpha 24$ 陽性 $T$ 細胞は一部クローナルに増加し、健 常人で多く発現する invariant $V a 24 \mathrm{~J} \alpha \mathrm{Q}$ 遺伝子は、著減していた。

【結語】V $\alpha 24 \mathrm{~J} \alpha \mathrm{Q}$ 遺伝子が患者末梢血中では、選択的に隇少していることから、V $\alpha 24 \mathrm{~J} \alpha \mathrm{Q}$ 陽性 T細胞が、自己免疫疾患に調節性細胞として関与している可能性が示唆された。 


\section{W 9-7}

TCR ワクチンの作用機構 : 脳炎惹起性 T細胞による TCR ペプチドの抗原 提示と TCR 特異的調節性 T細胞の活性化

山村 隆, Milena Kozovska, 田平 武

（国立精神・神経センター 第六部）

[目的] TCR Vß17a-50-68ペプチド（17a）は、SJL/J マウスにおいて MBP 特異的 T細胞の誘導を阻害し EAE も抑制する。しかし、ペプチド特異的T細胞の存在は証 明できず、その作用機構は謎のままであった。われわれは最近、脳炎炭起性 T細胞ク ローン $4 \mathrm{~b} .14 \mathrm{a}$ を抗原提示細胞として使用することにより $17 \mathrm{a}$ 特異的 T細胞の誘導を 証明することができた。今回はこの新しい現象について解析を加えた。

[方法]17aペプチド感作脾細胞(SpC)を調精し、放射線照射した $4 \mathrm{~b} .14 \mathrm{a}$ の存在下に、

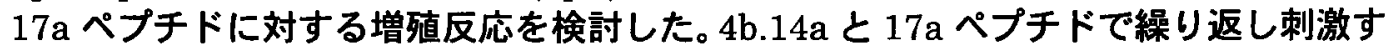
ることによって、17a 特異的丁細胞株を 3 株樹立した。

[結果・考察] 感作 $\mathrm{SpC}$ に 17a ペプチドを添加したのみではT細胞増殖は観察され ないが、4b.14a の存在下では強い特異的増殖反応が得られた。17a でパルスした 4b.14a にも SpC を刺激する活性があり、4b.14a は抗原提示細胞として働いているこ とが証明された。樹立されたT細胞株は CD4-CD8-のダブル・ネガテイブT細胞が優 勢で、MHC クラス I 拘束性であった。さらに $17 \mathrm{a}$ 特異的 T細胞株の受け身移入によ り、MBP による EAE が著明に抑制された。TCR ワクチンの作用機構として、TCR ペプチドを提示する $\mathrm{T}$ 細胞と調節性 $\mathrm{T}$ 細胞間相互作用の重要性が示された。 